\title{
Healthcare Networks in Metropolitan Areas - The Case of the Health System in Brazil
}

\author{
By Juliana Pires de Arruda Leite* \\ Ana Maria Carneiro ${ }^{\dagger}$
}

The health care system in Brazil is an example of the complexity and often fragmentation in health policy implementation. The notion of healthcare networks proposes that the health system must be organized through coordinated points to provide continuous and integrated care, based on cooperation between managers, providers, and users. In Brazil in 2010, the Ministry of Health enacted an ordinance defining the healthcare network as a management model to be pursued by the national health policy in order to address most of the difficulties of fragmentation. This paper proposes to discuss the cases of Healthcare Networks in Brazilian metropolitan regions, characterizing its implementation process as well as identifying management problems in various cases. This study is grounded on data provided by agencies responsible for health management in the federal and state levels, as well as the current literature on healthcare networks. Results include the analysis of metropolitan networks implemented within their different stages, challenges and advances.

Keywords: Brazil, Fragmentation, Health Care Networks, Health Management

\section{Introduction}

Health care systems are social responses deliberately organized to meet the demands and preferences of societies. In this sense, they must be linked to the health needs of these societies, which are expressed in unique demographic and epidemiological situations. There is therefore a close relationship between the evolution of the health conditions of a given population and the transition of health care systems.

There is currently a global crisis in health care systems, which reflects the mismatch between an epidemiological situation dominated by chronic conditions and a health care system aimed primarily at responding to acute conditions. The World Health Organization (WHO) states that, historically, acute problems such as infectious diseases and traumas are the main concern of health care systems, and warns: "To cope with the rise of chronic conditions, it is imperative that health systems transpose this predominant model" (World Health Organization 2003: 46).

In this sense, new proposals for chronic condition care are gaining strength worldwide through a coordinated and continuous system. The notion of integrated health care is one of the pillars of Healthcare Networks (HN), which are based on cooperation between managers, providers, and users.

${ }^{*}$ Professor, University of Campinas, Brazil.

${ }^{\dagger}$ Researcher, University of Campinas, Brazil. 
Contemporaneously, HNs took shape with integrated health systems deployed in the early 90 s in the United States.

Many countries have already had successful experiences in integrating their health systems by implementing Healthcare Networks. Brazil is progressing in this direction and in order to cope with most of the fragmentation difficulties, the Ministry of Health was sought to strengthen the design of networks in the operation of the National Health System (Brasil. Ministério da Saúde 2010).

One of the first steps towards the development of the healthcare networks is the definition of a restricted population whose overall health will be under the network's care. The definition of this population involves a regionalization process, whereby "health regions" are defined. These health regions do not always coincide with the political and administrative boundaries. This raises the challenge of cooperative management in the network. Therefore, an articulation of different bodies, agencies, and levels of government is necessary for the proper functioning of the network.

This scenario of inter-regional relations gains greater density when the territory is configured in an urban superstructure, as it is in the case of metropolitan regions. In these regions, the conurbation process dissolves the municipal administrative boundaries and requires cooperation between different cities in the search for economies of scale and scope in their health systems. In this sense, an analysis of the implementation of health care networks on a metropolitan scale is very fruitful.

Thus, this paper proposes to discuss the cases of Healthcare Networks in Brazilian metropolitan regions, characterizing its implementation process as well as identifying management problems in several cases. The study is based on data provided by agencies responsible for health management in the federal, state, and municipal levels, as well as the current literature on healthcare networks.

The paper is divided into six sections, including this introduction. The following two sections present the international literature review on health system networks and the Brazilian Health System, respectively. Then, the data relating to metropolitan regions and the experiences of healthcare network in these areas are discussed. The last two sections present the results and the final remarks highlighting the progress achieved and the challenges to face for the consolidation of healthcare networks in Brazil, respectively.

\section{Literature Review}

Healthcare Networks were first proposed in the Dawson Report, as requested by the British Government, and published in 1920 (Dawson 1964). The main subjects were: the integration of preventive and curative medicine, the central role played by the general practitioner, the entrance into the health system through the Primary Health Care, secondary care provided in outpatient clinics and tertiary care in hospitals. 
Despite the HN's having their origins in the Dawsonian conception of public health systems, they take shape, contemporaneously, with the integrated health systems implemented in the early 1990s, in the United States. According to Shortell et al. (1993), a pioneer study on health care networks in the United States, the integrated delivery of health services are characterized by: focus on the health needs of the population, coordination and integration of health care as a continuum, information systems that connect consumers, providers and paying agents, use of financial incentives and organizational structures to align governance, managers and health professionals to achieve objectives, and continuous improvement of provided services.

Considering such elements above, one can define the organized health care system based on the concept of integration. According to the international literature the most frequent taxonomies of health care systems are related to the types of integration (functional or clinical), to the extension of integration (horizontal or vertical), the process of integration (structural, cultural or social), and to the degree of integration (collaborative and complete) (Simoens and Scott 1999).

When discussing the impacts of integrated health systems, Wan et al. (2002) found that more integrated systems had greater potential to provide a continuum of coordinated care and a greater efficiency in hospitals. The reasons were the integration of processes and services, the governance structure, the multidisciplinary work, the clinical integration and the integrated information systems.

Pointer et al. (1997) summarized a historical description of integrated health systems and identified the key elements in these systems: the responsibility for a population, the focus on improving health levels of the population, the provision of a continuum of services, the clinical integration and the capitation payment. As it follows, we present some different experiences of healthcare networks, published in the international literature.

Leat et al. (1996) analyzed the Canadian public health system in several provinces and found out a fragmented situation. Based on this diagnosis, they proposed the integration of the system by defining a population of responsibility, a capitation payment, the institution of the family doctor as an entrance way into the system, the supply of comprehensive services, the strengthening of the health information and the planning based on population needs. The Canadian Institute for Health Information (2003) evaluated the participation of hospitals in the province of Ontario and concluded that $70 \%$ of hospitals had one or more integration experiences, $64 \%$ reported belonging to a strategic alliance and $59 \%$ were found to be integrated with the community's health centers and mental health units.

In the United States, Griffith (1997) analyzed the conversion of community hospitals into integrated health care organizations and identified some success factors: the combination of internal and external leadership, the greater participation of doctors, the strengthening of the Primary Health Care (PHC) and the introduction of clinical governance by the implementation of clinical guidelines. Enthoven (1988) defended the integration of the American 
health system as a way to overcome its crisis. From an economic point of view, the author also stated that the advantages of integration derives from a welldefined population-based system, from the efficiency of the attention in the right place, from the integration between different health professionals and from the coordination role of PHC.

In Western Europe's public health care systems, the HNs have been increasingly introduced. Saltman and Figueras (1997) analyzed health reforms in Europe and devoted a chapter in their survey to the "substitution" process, which reorganizes the relationships between different points of health care systems. This process of reorganization had major impacts on hospital care.

Sunol et al. (1999) reported the implementation of comprehensive care plans in Spain with the following structure: the attention to the healthy population, the attention to risk factors, the diagnosis and the first treatment, the initial phase of treatment, the advanced stage of treatment and the terminal phase.

Micaleff (2000) studied the HNs in France, where the focus is in some specific problems such as HIV/AIDS, drug addiction, diabetes and hepatitis C. Hildebrandt and Rippman (2001) discussed HNs in Germany. Since 2000, the health legislation induced the formation of HNs in this country, with medical and economic integration services, integration of outpatient and hospital services, integration of pharmacists and nursing services, continuity of care and incentives for promotional and preventive actions. Warner (2001) focused on the examination of care chains introduced in Sweden, in the Netherlands and in the UK and defined their critical factors: a focused attention on users, the active control of flows within the system, the articulated logistics systems, the highly integrated information system, the absence of economic barriers and the placement of services under a single management.

Regarding the recent reform of the health care system in the UK, Ham (2006), showed that it was concentrated in inducing the competition instruments, although he considers that the next stage of the reform must be done with collaboration mechanisms through the implementation of HNs.

In Latin America healthcare networks are incipient. There are reports of experiences in Peru (Ministerio de la salud de Peru 1999), Bolivia (Lavadenz et al. 2001) and Colombia (Vásquez and Vargas 2006), but the most consolidated experience seems to be Chile, where HNs have been discussed for some time and are an official policy of the Ministry of Health (Ministerio de la salud de Chile 2005, Fábrega 2007).

In Brazil, the issue has only been recently treated, but with a growing trend. This experience will be reported below, as showed in the results of this paper.

\section{The Brazilian Health System}

Until the 1930s, a national health system did not properly exist in Brazil. The effective state of health intervention began in that decade and consolidated 
its profile until the mid-1960s. The standard established in this period was a centralized federal government policy. Until the mid-1970s the system expanded the service coverage significantly, increasing the volume of users. However, this growth dictated the need to reform the system, which began to suffer from its own gigantic size. Thus, in the second half of the 1970s, the pressures for a reform based on the integration of the three levels of government (federal, state, and municipal) and on decentralization increased. It is in this context that in the 1980s, especially with the promulgation of the Federal Constitution (FC 1988), the country began to form a new system of universal public health, called the Unified Health System (UHS) (Draibe and Aureliano 1989).

In 1993, the Standard Operating Base of UHS marked the first steps towards an administrative decentralization of the health system. This standard explicitly defined the municipality as the manager of health services and established the responsibilities and the forms of funding. In addition, it established the management arrangements between the three government levels (federal, state, and municipal) (Brasil. Ministério da Saúde 1993).

After the process of decentralization in the 1990s, regionalization has occupied a prominent role in the national health policy during the 2000s. In this context, agreements between the Ministry of Health and other levels of government to consider the welfare priorities of each state were signed, subdividing the system into regions and micro-regions of health (Brasil. Ministério da Saúde 2001).

The strategies towards comprehensive care went through the deployment and consolidation of a new model of primary care; the Family Health Program. This program is operated by multidisciplinary teams in primary healthcare units. Each team is responsible for monitoring a maximum of 4,000 inhabitants of a given area. The Family Health Program structured in local health systems has led to a major reorganization of the care model and produced positive results in major health indicators of the assisted populations (Brasil. Ministério da Saúde. Secretaria de Atenção à Saúde. Departamento de Atenção Básica 2008).

The debate on the further integration of the health system acquired new emphasis from the publication of the document "Health Pact" (Brasil. Ministério da Saúde 2006), which emphasizes the importance of deepening the process of regionalization and organization of the system into an integrated manner. Advancing further in this direction in 2010, the Ministry of Health sought to strengthen the design of networks in the operation of the UHS, with the publication of one ordinance concerning the organization of the Healthcare Networks. This ordinance defines healthcare networks as "organizational arrangements, actions, and health services to be integrated by technical, logistical, and management support systems, seeking to ensure comprehensive care" (Brasil. Ministério da Saúde 2010: 5).

Since then, some implementation strategies have been established and are in progress for the construction of this new model of care in networks. Through technical and financial support, the Ministry of Health has prioritized and 
promoted the implementation of thematic networks, such as: "Stork Network" (Comprehensive care of pregnant, postpartum, and children up to 24 months), Emergency Care Network, Psychosocial Care Network (with priority for addressing alcoholism, crack addiction, and other drugs), Network of Care for Persons with Disabilities, Occupational Health Network, Elderly Health Network, among others (Brasil. Ministério da Saúde 2010).

Among the tools to manage these thematic networks, the most used in the Brazilian model is the creation of Lines of Care (LC) (Franco and Magalães 2004). The Lines of Care are a form of joint resources and production practices among health care units in a given region for timely, responsive, and unique treatment of users by way of diagnosis and therapy. The goal is to coordinate care along the continuum and the connectivity of roles and tasks of different professionals and points of attention. The implementation of the LC occurs from the Primary Health Units, which have responsibility for care coordination and management of the network. Examples of lines of care implemented in the Brazilian system are: Arterial Hypertension Line Care, Diabetes Mellitus Line Care, Acute Myocardial Infarction Line Care, Stroke Line Care, Trauma Care Line, Breast Cancer Line Care and others (Brasil. Ministério da Saúde 2010).

\section{The Metropolitan Challenge}

In this section we intend to briefly characterize the Brazilian Metropolitan Regions (MRs) and contextualize them in the national health system. In addition, we seek to highlight some factors that make the integration of health services in these regions a complex challenge. Finally, we present the evidence found on the implementation of healthcare networks in some metropolitan regions. 
Table 1. Demographics of Brazilian Metropolises, 2010

\begin{tabular}{|c|c|c|c|}
\hline Metropolitan Region & $\begin{array}{c}\text { Number of } \\
\text { Municipalities }\end{array}$ & $\begin{array}{l}\text { Number of } \\
\text { Inhabitants }\end{array}$ & $\begin{array}{c}\% \text { of the State } \\
\text { Population }\end{array}$ \\
\hline São Paulo & 39 & $19,683,975$ & $47.7 \%$ \\
\hline Rio de Janeiro & 19 & $11,835,708$ & $74.0 \%$ \\
\hline Belo Horizonte & 48 & $5,414,701$ & $27.6 \%$ \\
\hline Porto Alegre & 31 & $3,958,985$ & $37.0 \%$ \\
\hline Brasília* & 22 & $3,717,728$ & - \\
\hline Recife & 14 & $3,690,547$ & $41.9 \%$ \\
\hline Fortaleza & 15 & $3,615,767$ & $42.8 \%$ \\
\hline Salvador & 13 & $3,573,973$ & $25.5 \%$ \\
\hline Curitiba & 26 & $3,174,201$ & $30.4 \%$ \\
\hline Campinas & 19 & $2,797,137$ & $68 \%$ \\
\hline Goiânia & 20 & $2,173,141$ & $36.2 \%$ \\
\hline Manaus & 8 & $2,106,322$ & $60.5 \%$ \\
\hline Belém & 6 & $2,101,883$ & $27.7 \%$ \\
\hline Vitória & 7 & $1,687,704$ & $48.0 \%$ \\
\hline Baixada Santista & 9 & $1,664,136$ & $4.0 \%$ \\
\hline Natal & 10 & $1,351,004$ & $42.6 \%$ \\
\hline São Luís & 5 & $1,331,181$ & $20.2 \%$ \\
\hline João Pessoa & 13 & $1,198,576$ & $31.8 \%$ \\
\hline Maceió & 11 & $1,156,364$ & $37.0 \%$ \\
\hline Teresina & 14 & $1,150,959$ & $36.9 \%$ \\
\hline NE Santa Catarina & 20 & $1,094,412$ & $17.5 \%$ \\
\hline Florianópolis & 22 & $1,012,233$ & $16.2 \%$ \\
\hline Aracaju & 4 & 835,816 & $40.4 \%$ \\
\hline Cuiabá river & 4 & 833,766 & $27.5 \%$ \\
\hline Londrina & 8 & 764,348 & $7.3 \%$ \\
\hline Vale do Itajaí & 16 & 689,731 & $11.0 \%$ \\
\hline Campina Grande & 23 & 687,039 & $18.2 \%$ \\
\hline Petrolina/Juazeiro* & 8 & 686,410 & - \\
\hline Vale do Aço & 26 & 615,297 & $3.1 \%$ \\
\hline Maringá & 13 & 612,545 & $5.9 \%$ \\
\hline Agreste Alagoano & 20 & 601,049 & $19.3 \%$ \\
\hline Cariri & 9 & 564,478 & $6.7 \%$ \\
\hline Carbonífera & 25 & 550,206 & $5.1 \%$ \\
\hline Foz do Itajaí & 9 & 532,771 & $8.5 \%$ \\
\hline Macapá & 2 & 499,466 & $74.6 \%$ \\
\hline Chapecó & 25 & 403,494 & $6.5 \%$ \\
\hline Tubarão & 18 & 356,721 & $5.7 \%$ \\
\hline Lages & 23 & 350,532 & $5.6 \%$ \\
\hline Southwest Maranhão & 8 & 345,873 & $5.3 \%$ \\
\hline
\end{tabular}

Note: * Metropolitan regions composed by the conurbation of two or more states.

Source: Elaborated by authors based on IBGE, Population Census (2010).

The first metropolitan regions of Brazil were formally created between the 1960s and 1970s. Currently, there are 39 metropolises in Brazil, which are not only characterized by a concentration of most of the national population and wealth, but also by having significant pockets of poverty and social exclusion. 
The metropolitan municipalities differ substantially from each other as to the metropolization process, i.e., levels of population density and economic activities, which hinders the formulation of public policies for these regions. Table 1 characterizes the Brazilian metropolitan regions with respect to demographics.

The data show extensive heterogeneity with respect to the number of cities and population representativeness. The number of cities that make up the metropolitan regions (MRs) vary from 2 to 48. There are nine MRs which represent more than $40 \%$ of their state's population. There are also MRs composed of numerous small municipalities, which do not have a significant population. This can be explained by the fact that some states have more than one metropolitan area.

With respect to the health system in Brazil, the direct relationship of the Union with municipalities (a result of the decentralization process) imposed difficulties for the challenge of metropolitan health management. The gain of municipal autonomy contributed to generate an "institutional vacuum" in the metropolitan scale, to the extent that the metropolitan regions, although recognized by the Constitution, are not federal entities, i.e., autonomous units of government. This ambiguous legal situation emphasizes the difficulties in integrating the planning and the implementation of health policy (among many other urban policies), and expresses a reality still quite permeated by conflicts and uncertainties about the compromising level of action (Garson, 2007). Table 2 presents the data for the Health System in metropolitan regions ${ }^{1}$.

The number of doctor consultations per person in metropolitan areas varies between 1.57 and 6.65; the national average is 2.77, therefore 9 (30\%) metropolitan regions outweigh the national average. Hospitalizations per 100 inhabitants varies between 3.35 and 6.97 with the national average being 5.67, which means that $14(46.7 \%)$ metropolitan regions exceed this average. The number of hospital beds (attended by the Unified Health System) per 1,000 inhabitants varies from 0.92 to 2.43 . As the average of Brazil is $1.69,17$ $(56.7 \%)$ metropolitan regions have values that surpass it. Finally, the number of health professionals occupying top-level jobs have the greatest variation (2.7 to 9.4$)$ and $19(63 \%)$ regions exceed the national average.

\footnotetext{
${ }^{1}$ Health data were not available for 9 of the 39 metropolitan regions (Manaus, Aracaju, Cuiaba river, Campina Grande, Agreste Alagoano, Cariri, Chapecó, Lages and southwest of Maranhão).
} 
Table 2. Health Data in Brazilian Metropolitan Regions, 2012

\begin{tabular}{|c|c|c|c|c|}
\hline $\begin{array}{l}\text { Metropolitan } \\
\text { Region }\end{array}$ & $\begin{array}{c}\text { Doctor } \\
\text { Consultation } \\
\text { per Person }\end{array}$ & $\begin{array}{c}\text { Hospitalization } \\
\text { per 100 } \\
\text { Population }\end{array}$ & $\begin{array}{c}\text { Hospital } \\
\text { Beds per } \\
1,000 \\
\text { Population }\end{array}$ & $\begin{array}{c}\text { Number of } \\
\text { Higher } \\
\text { Education } \\
\text { Professionals } \\
\text { in Health per } \\
\text { 1,000 } \\
\text { Population* }\end{array}$ \\
\hline São Paulo & 3.09 & 4.96 & 1.17 & 2.70 \\
\hline Rio de Janeiro & 2.21 & 3.35 & 1.7 & 2.93 \\
\hline Belo Horizonte & 2.37 & 5.05 & 1.44 & 3.59 \\
\hline Porto Alegre & 2.58 & 6.58 & 1.83 & 4.07 \\
\hline Brasília & 2.44 & 5.16 & 1.36 & 4.23 \\
\hline Recife & 2.69 & 6.02 & 2.33 & 4.44 \\
\hline Fortaleza & 1.74 & 4.84 & 1.86 & 4.65 \\
\hline Salvador & 2.52 & 4.97 & 1.72 & 4.96 \\
\hline Curitiba & 2.55 & 6.47 & 1.81 & 5.25 \\
\hline Campinas & 2.7 & 4.54 & 0.98 & 5.28 \\
\hline Goiânia & 2.45 & 6.23 & 2.18 & 5.62 \\
\hline Belém & 2.7 & 5.94 & 1.58 & 5.99 \\
\hline Vitória & 2.83 & 5.01 & 1.32 & 6.00 \\
\hline Baixada Santista & 3.46 & 4.47 & 0.92 & 6.03 \\
\hline Natal & 2.37 & 4.56 & 1.79 & 6.32 \\
\hline São Luís & 3.42 & 5.18 & 2.43 & 6.90 \\
\hline João Pessoa & 2.48 & 6.2 & 2.35 & 7.01 \\
\hline Maceió & 3.3 & 5.08 & 2.25 & 7.08 \\
\hline Teresina & 2.36 & 5.79 & 2.19 & 7.10 \\
\hline NE Santa Catarina & 2.33 & 5.31 & 1.37 & 7.29 \\
\hline Florianópolis & 2.87 & 5.21 & 2.41 & 7.41 \\
\hline Londrina & 3.32 & 6.79 & 2.03 & 7.56 \\
\hline Vale do Itajaí & 6.65 & 5.99 & 1.1 & 7.74 \\
\hline Petrolina/Juazeiro & 1.9 & 5.91 & 1.18 & 7.74 \\
\hline Vale do Aço & 1.57 & 5.39 & 1.19 & 8.11 \\
\hline Maringá & 2.54 & 6.97 & 1.76 & 8.19 \\
\hline Carbonífera & 3.59 & 6.61 & 1.85 & 8.29 \\
\hline Foz do Itajaí & 2.54 & 5.66 & 1.26 & 8.72 \\
\hline Macapá & 1.86 & 5.67 & 1.37 & 9.11 \\
\hline Tubarão & 2.35 & 6.76 & 1.83 & 9.40 \\
\hline BRAZIL & 2.77 & 5.67 & 1.69 & 5.69 \\
\hline
\end{tabular}

Note: $*$ Reference Year $=2009$.

Sources: Biblioteca Virtual em Saúde da Rede Interagencial de Informações para a Saúde (2012), Brasil. Ministério da Saúde (2012), IBGE - Medical and Health Care Research (2009) and IBGE (2010). 
With regard to data on healthcare networks in metropolitan regions, evidence of HNs was found in 16 of 39 metropolitan regions ${ }^{1}$. Due to the aforementioned recent ordinance of the Ministry of Health (Brasil. Ministerrio da Saúde 2010), the experiences of HNs are beginning to spread across the country. However, it is an ongoing process. Thus, the status progress analysis was made based on the following criteria:

- Incipient: Experiences reporting that teams of State Health Departments are discussing internally what HNs are, performing educational processes to the central level for institutional support.

- In consolidation: Experiences reporting development of the first steps in organizing $\mathrm{HN}$ : definition of health regions; mapping of resources and needs; approach with other actions; meeting of regional boards; defining flows.

- Consolidated: Experiences reporting results of networks in action through monitoring and evaluation indicators of $\mathrm{HN}$.

It is worthy to say that this phenomenon takes place in $41 \%$ of the MRs. For all the records found in the present study, 9 (56\% of this subtotal) HNs' cases were classified as "incipient" and $7(44 \%)$ as "in consolidation" process. No evidence cases already consolidated with published results were found. Conass (2012) also found that in most states the healthcare networks are in the early stages of their processes, which corroborates the evidence found for the metropolitan regions in this research. Table 3 presents the data for the Healthcare Networks in metropolitan regions.

As a whole, the implementation experiences of 11 different thematic healthcare networks in metropolitan regions were registered. Undoubtedly the most developed thematic network so far is the "Stork Network" (SN Comprehensive care for pregnant women, postpartum, and children), present in 14 of the 16 regions. The second most important network deployment is the Emergency Care Network (present in 9 MRs), followed by the Psychosocial Care Network (3 MRs), the Elderly Health Network (3 MRs), the Network of care for People with Disabilities (2 MRs), the Occupational Health Network (2 MRs), the Adolescent Health Network (2 MRs), the Mental health Network (1 MR), and lastly the Women Health Network (1 MR).

These results corroborate those found in Conass (2012), which published the papers presented at the event "The State and Healthcare Networks: 1st Show of experiences". This publication compiles the experiences of HNs in Brazil (not necessarily metropolitan regions). The results of this publication also show that the most developed network in the country is the "Stork Network", then the Emergency Care Network.

\footnotetext{
${ }^{1}$ The evidence concerning the existence of HNs and Lines of Care in different metropolitan regions were obtained from several sources: state and municipal Departments of Health, scientific publications that report experiences, news reports and newsletters. As this is a recent process in consolidation in the country, for some MRs evidence of HN deployment were not found.
} 
Table 3. Healthcare Networks in Brazilian Metropolitan Areas

\begin{tabular}{|c|c|c|c|c|}
\hline Metropolitan Region & Thematics Healthcare Networks & Lines of care & Process Status & Sources \\
\hline Manaus & $\mathrm{SN}$ & $\mathrm{PP}-\mathrm{LC}$ & Incipient & Governo do Estado do Amazonas (2011) \\
\hline Belém & SN, ECN, PCN, NPD & $\begin{array}{c}\mathrm{PP}-\mathrm{LC}, \\
\mathrm{CVA} / \mathrm{AMI}-\mathrm{LC}, \\
\text { ACD }-\mathrm{LC} \\
\end{array}$ & Incipient & $\begin{array}{l}\text { Estado do Pará (2012), } \\
\text { Prefeitura de Belém (2012) }\end{array}$ \\
\hline Fortaleza & SN, ECN, PCN, NPD, OHN & $\begin{array}{c}\mathrm{PP}-\mathrm{LC}, \\
\text { CVA/AMI - LC, } \\
\text { ACD - LC, } \\
\text { EH - LC, } \\
\text { AH - LC }\end{array}$ & In consolidation & $\begin{array}{l}\text { Secretaria da Saúde do Estado do Ceará } \\
\qquad(2012,2014)\end{array}$ \\
\hline Recife & SN, EHN, AHN & $\begin{array}{c}\mathrm{PP}-\mathrm{LC}, \\
\mathrm{ACD}-\mathrm{LC}, \\
\mathrm{EH}-\mathrm{LC}, \\
\mathrm{AH}-\mathrm{LC}\end{array}$ & Incipient & $\begin{array}{c}\text { Governo do Estado de Pernambuco (2014), } \\
\text { Prefeitura do Recife (2009) }\end{array}$ \\
\hline Salvador & $\mathrm{SN}, \mathrm{ECN}$ & $\begin{array}{l}\mathrm{PP}-\mathrm{LC} \\
\mathrm{TC}-\mathrm{LC}\end{array}$ & In consolidation & $\begin{array}{l}\text { Secretaria de Saúde do Estado da Bahia } \\
(2012 a, 2012 b)\end{array}$ \\
\hline Belo Horizonte & SN, ECN, EHN & $\begin{array}{l}\mathrm{PP}-\mathrm{LC} \\
\mathrm{OO}-\mathrm{LC}\end{array}$ & In consolidation & $\begin{array}{l}\text { Prefeitura de Belo Horizonte } \\
\qquad(2009,2014)\end{array}$ \\
\hline Vale do Aço & SN, ECN, WHN & $\begin{array}{c}\mathrm{PP}-\mathrm{LC}, \\
\mathrm{CVA} / \mathrm{AMI}-\mathrm{LC}, \\
\mathrm{BC}-\mathrm{LC}\end{array}$ & Incipient & Gama (2009), Diário do Aço (2013) \\
\hline Vitória & SN & $\mathrm{PP}-\mathrm{LC}$ & Incipient & $\begin{array}{l}\text { Portal Brasil (2014), Estado do Espírito } \\
\text { Santo (2012) }\end{array}$ \\
\hline Rio de Janeiro & $\mathrm{SN}, \mathrm{ECN}, \mathrm{PCN}$ & $\begin{array}{c}\mathrm{PP}-\mathrm{LC}, \\
\mathrm{CVA} / \mathrm{AMI}-\mathrm{LC}, \\
\text { ACD }-\mathrm{LC} \\
\end{array}$ & In consolidation & $\begin{array}{l}\text { Governo do Rio de Janeiro (2014), } \\
\text { Prefeitura da Cidade do Rio de Janeiro } \\
\text { (2014) }\end{array}$ \\
\hline São Paulo & SN, ECN, EHN, HCN & $\begin{array}{c}\mathrm{PP}-\mathrm{LC}, \\
\text { CVA/AMI - LC, } \\
\text { ACD - LC, } \\
\text { TC - LC, } \\
\text { BC - LC, } \\
\text { HA - LC }\end{array}$ & In consolidation & $\begin{array}{l}\text { Secretaria de Saúde de São Bernardo do } \\
\text { Campo (2012), Bombarda (2012), Governo } \\
\text { do Estado de São Paulo (2014) }\end{array}$ \\
\hline Campinas & $\mathrm{SN}, \mathrm{NCD}$ & $\begin{array}{l}\mathrm{PP}-\mathrm{LC} \\
\mathrm{D}-\mathrm{LC}\end{array}$ & Incipient & Agência Metropolitana de Campinas (2012) \\
\hline
\end{tabular}




\begin{tabular}{|c|c|c|c|c|}
\hline Curitiba & SN, ECN & $\begin{array}{c}\text { PP - LC, } \\
\text { CVA/AMI - LC }\end{array}$ & In consolidation & $\begin{array}{c}\text { Prefeitura de Curitiba (2013), Coordenação da Região } \\
\text { Metropolitana de Curitiba (2014) }\end{array}$ \\
\hline Londrina & AHN & $\begin{array}{c}\text { AH - LC, } \\
\text { CH - LC }\end{array}$ & Incipient & Prefeitura de Londrina (2013) \\
\hline Porto Alegre & SN, OHN, MHN & $\begin{array}{c}\text { PP - LC, } \\
\text { AH - LC, } \\
\text { BC - LC, } \\
\text { MH - LC }\end{array}$ & In consolidation & $\begin{array}{c}\text { Governo do Estado do Rio Grande do Sul } \\
(2011,2014 a, 2014 b)\end{array}$ \\
\hline Goiânia & ECN, PCN & TC - LC & Incipient & $\begin{array}{c}\text { Prefeitura de Goiânia (2012), Secretaria da Saúde do Estado de } \\
\text { Goiás (2013) }\end{array}$ \\
\hline Brasília & SN & PP - LC & Incipient & $\begin{array}{c}\text { Secretaria de Estado de Desenvolvimento da Região } \\
\text { Metropolitana do Distrito Federal (2014), Secretaria de Estado } \\
\text { de Saúde do Distrito Federal (2014) }\end{array}$ \\
\hline
\end{tabular}

Source: Elaborated by authors.

\section{Legend:}

\section{Thematic Networks:}

SN: "Stork Network" (Comprehensive care to pregnant, postpartum and child)

ECN: Emergency Care Network

PCN: Psychosocial Care Network

NPD: Network of Care for Persons with Disabilities

OHN: Occupational Health Network

EHN: Elderly Health Network

AHN: Adolescent Health Network

HCN: Home Care Network

MHN: Mental Health Care Network

WHN: Women Health Network

NCD: Network of Attention to Chronic Diseases

\section{Lines of Care:}

PP - LC: Pregnant and Postpartum Line of Care

CVA/AMI - LC: Cerebrovascular Accident (CVA) and Myocardial Infarction (AMI) Line of Care

ACD - LC: Coping with Alcohol, Crack and Other Drugs Line of Care

EH - LC: Elderly Health Line of Care

AH - LC: Adolescent Health Line of Care

$\mathrm{CH}$ - LC: Children Health Line of Care

TC - LC: Traumatology and Cardiovascular Line of Care

OO - LC: Ophthalmology and Otolaryngology Line of Care

BC - LC: Breast and Cervical Cancer Line of Care

HA - LC: Arterial Hypertension Line of Care

D - LC: Diabetes Line of Care

MH - LC: Mental Health Line of Care 


\section{Discussion}

In this section we will discuss the results and compare them with other empirical studies of healthcare networks.

The Brazilian health system can be characterized for its great scale and its decentralized management model (the system is implemented by its 5,570 municipalities). As one can see both in the demographics and in the health system data, there are large regional differences between the metropolitan areas. These inequalities extend to other regions of the country.

In order to mitigate inequalities and provide a more homogeneous care across the country, the Health Ministry implements strong national "top-down" policies that seek uniformity by municipalities. The healthcare network policy is one of them. This policy is in a very early stage of implementation, and was institutionalized only in 2010. There is no data about efficiency and effectiveness of the healthcare networks in Brazil (since it is a recent case). The comparison with other empirical cases will be made in terms of structure and management processes.

From the experiences studied in Brazil, we could notice some points that represent progress in consolidating the healthcare networks in Brazilian metropolitan regions as well as points that express the difficulties and obstacles to be faced in this trajectory.

As progress we can cite the approach and the integration movement taken by different areas of the state Health Departments in articulating shared planning and implementation of strategies and actions. In some cases this integration fostered the articulation of different projects and programs developed by optimizing the use of resources. Another positive point to be noted was the attempt to improve the dialogue between the various levels of government (municipal, regional, state, and federal) for the convergence of the projects and actions. Finally, the movement of dissemination and socialization of existing experiences in various institutions provides a constant construction and consolidation dynamic for this new model of care.

On the other hand, some difficulties were quite clear, for example, the need to redefine the funding criteria that remain fragmented and dissociated from this new form of organization. In addition, several reports suggest that the integration of information systems is the main challenge faced by the consolidation of networks in the Brazilian health system. Other bottlenecks include the establishment of criteria to define the populations ascribed to health regions, the lack of commitment of some municipalities with planning activities, and the undeveloped culture of monitoring and evaluation of networks. Moreover, the integration of information systems has not yet been implemented and is configured as the biggest challenge to the advancement of HNs.

Seeking to show the similarities, to compare the differences and to enlighten some insights that can improve the Brazilian trajectory, the following paragraphs discuss four empirical studies of healthcare networks. 
Martínez (2004) published an empirical study of an integrated health services network in Catalonia. The network operates in an integrated way since 2001 (a decade of history before the Brazilian case). As similarities to the Brazilian case we find thematic networks (such as woman and childhood network, emergency network and operations network) and something similar to lines of care: "guides to clinical practice" and administrative circuits. However, in the Catalonian network the information system is fully integrated (hospitals, centers of primary care and offices), and all health care information (medical history) and administrative are scanned. As already stated, this integration is the biggest challenge for the Brazilian system.

Grenier (2011) highlights an empirical case study, of a healthcare network in France. This is a thematic network of elderly care, also implemented in 2001. Unlike Brazil, this network emerged from the "bottom-up" perspective, not a mandate one. But similarly, the government defines the organization and management methods through regulatory channels and encourages professionals, organizations and patients to adopt them. The study reports that at the beginning of the network development, the various stakeholders had different views on what a healthcare network was, so it was necessary firstly to align the concept - this is what is happening now in some regions of Brazil. The author reported a structuring model that can be valuable to the networks in Brazil. He reported the structure in 2 stages, as follows:

"Focus (purpose of the network), and then expansion (integration of the various actors); this process was made possible by enacting the diversity of the actors involved and by the specific role played by the two leaders" (Grenier 2011: 9).

Holden and Lin (2012) present an empirical study of the Men's Health network in Australia. As in the French case, the network is a bottom-up initiative, and the oldest among the reported studies (had its beginning in 1996). However, despite the longer time of implementation, the study reports that the network suffers from problems of coordination and defines the network as "loosely coupled network":

"When policy is developed in a sector with a loosely coupled network of interdependent actors as in this case study, policy implementation may be hindered by a lack of program and service co-ordination between key, but essentially independent, stakeholders" (Holden and Lin 2012: 233).

Finally, Barnett et al. (2009) describes the modes of governance and health care networks in New Zealand. This case reserves a fundamental difference with the Brazilian case. This is a country with 4 million inhabitants, compared with more than 200 million in Brazil. Regarding the management model there are similarities: New Zealand also has a decentralized structure, but with strongly directed national policies. The New Zealand case also reported problems with the heterogeneity of the health regions ("health districts"). A 
lesson that Brazil could take from New Zealand's experience is the tradition of great commitment and popular participation in health policy (their management councils are elected directly), which includes indigenous participation. Thus, in this country, management mechanisms were consolidated on these bases. However, Barnett et al. (2009) acknowledge that this is a heterogeneous and sometimes slow process of construction:

"Within a single system network, modes of governance, despite statutory guidelines, are likely to develop in variable ways, sometimes slowly" (Barnett et al. 2009: 26).

\section{Conclusions}

This article aimed to describe the Brazilian experience in the implementation of healthcare networks. In addition, we highlighted some evidence from international literature that showed the trends in many countries towards the integration of health systems, considering the new context of prevalence of chronic diseases.

The Brazilian experience shows a very large system, managed in a decentralized manner. Healthcare networks, which are the national strategy for the integration of the health system, are at an early stage of deployment and require structural changes in such a system.

However, this scenario does not escape the expected. The Organización Panamericana de la Salud (2010) asserts that integration processes are difficult, complex, and long term based, when analyzing HNs experiences across America. This is because the integration processes requires larger systemic changes, not just isolated and targeted interventions. Considering this, one can say that Brazil is taking key steps towards this structural and systemic change in its health system.

Other countries report empirical cases where one can observe healthcare networks in higher levels of development, such as the ones with a consolidated popular participation and the ones with technological and informational integration. These cases may offer insights for Brazilian policymakers design the next stages of HNs in Brazil.

Future research might keep up with the evolution of healthcare networks in Brazil, and also in other countries, in order to enlighten the determinants of success as well as its impact on the welfare of the population served.

\section{References}

Agência Metropolitana de Campinas [Campinas Metropolitan Agency] (2012) [Online] Available at: http://bit.ly/1zJz3G0. [Accessed: 30 April 2014].

Barnett P, Tenbensel T, Cumming J, Clayden C, Ashton T, Pledger M, Burnette M (2009) Implementing new modes of governance in the New Zealand health system: an empirical study. Health Policy 93(2-3): 118-127. 
Biblioteca Virtual em Saúde da Rede Interagencial de Informações para a Saúde [Virtual Health Library of Interagency Information for Health Network] (2012) Indicadores e Dados Básicos - Brasil - 2012 [Indicators and Basic Data Brazil] [Online] Available at: http://bit.ly/1QhjSaZ. [Accessed: 22 March 2014].

Bombarda FP (2012) Redes Regionais de Atenção à Saúde [Regional Healthcare Networks] [Online] Available at: http://bit.ly/1bZqRGD [Accessed: 05 February 2014].

Brasil. Ministério da Saúde [Brazil, Ministry of Health] (1993) A Norma Operacional Básica do SUS 01/93 [The Basic Operational Norm of SUS 01/93] [Online] Available at: http://bit.ly/1FM6loZ [Accessed: 17 November 2013].

Brasil. Ministério da Saúde [Brazil, Ministry of Health] (2001) Norma Operacional da Assistência à Saúde/SUS 01/2001, Portaria $N^{o} 95$ [Operational Assistance Standard Health, Ordinance n. 95]. [Online] Available at: http://bit.ly/1dJBGO8 [Accessed: 19 September 2013].

Brasil. Ministério da Saúde [Brazil, Ministry of Health] (2006) Pacto pela Saúde 2006 Portaria n. 399/GM [Health Pact. Ordinance n. 399/GM] [Online] Available at: http://bit.ly/1F3cnTp [Accessed: 14 April 2014].

Brasil. Ministério da Saúde [Brazil, Ministry of Health] (2010) Diretrizes para a organização da Rede de Atenção à Saúde no SUS - Portaria $n^{\circ} 4.279$, de 30 de dezembro de 2010 [Guidelines for the organization of Healthcare Networks in SUS. Ordinance n. 4.279] [Online] Available at: http://bit.ly/1OW8XGy [Accessed: 9 March 2013].

Brasil. Ministério da Saúde [Brazil, Ministry of Health] (2012) Cadastro Nacional de Estabelecimentos de Saúde [National Register of Health Facilities] [Online] Available at: http://bit.ly/19ofDHq [Accessed: 22 March 2014].

Brasil. Ministério da Saúde - Departamento de Atenção Básica [Brazil, Ministry of Health - Primary care department] (2008) Saúde da Família no Brasil: Uma Análise de Indicadores Selecionados: 1998-2005/2006. [Family Health in Brazil: an Analysis of Selected Indicators: 1998-2005/2006] Brasília: Série C. Projetos, Programas e Relatórios.

Canadian Institute for Health Information (2003) Hospital Report 2003: Acute Care. Toronto: Government of Ontario/Ontario Hospital Association/University of Toronto.

Conass (2012) O Estado e as Redes de Atenção à Saúde: $1^{a}$ Mostra Nacional de Experiências. [The State and Healthcare Networks: 1st National Experiences show]. Cadernos de informação técnica no 25 [Technical information booklets $\mathrm{n}$. 25] [Online] Available at: http://bit.ly/1DPXc8S [Accessed: 18 April 2014].

Coordenação da Região Metropolitana de Curitiba [Coordination of the Metropolitan Region of Curitiba] (2014) [Online] Available at: http://bit.ly/lbZsR1x [Accessed: 30 April 2014].

Dawson B (1964) Informe Dawson Sobre el Futuro de los Servicios Médicos y Afines, 1920. [Dawson Report on the Future of Medicine and Related Services, 1920] Washington: PanAmerican Health Organization.

Diário do Aço [Steel Diary - newspaper] (2013) Rede de Urgência vai Integrar UPA de Ipatinga e Samu Regional - Diário do Aço 15 March [Emergency network will integrate UPA Regional Samu] [Online] Available at: http://bit.ly/1ABj0oI [Accessed: 23 April 2014].

Draibe S, Aureliano L (1989) A especificidade do Welfare State brasileiro. [The specificity of the Brazilian Welfare State] In: Brasil. Ministério de Previdência e Assistência Social (ed) [Brazil. Ministry of Health and Social Care] Brasília: CEPAL/MPAS 85-178. 
Enthoven A (1988) Managed competition of alternative delivery systems. Journal of Health Politics, Policy and Law 13(2): 305-321.

Estado do Espírito Santo. Secretaria de Estado da Saúde [State of Espirito Santo. Secretary of State for Health] (2012) Plano Estadual de Saúde 2012-2015 [State Health Plan 2012-2015] [Online] Available at: http://bit.ly/1IcIwIP [Accessed: 23 April 2014].

Estado do Pará. Secretaria de Estado de Saúde Pública [State of Pará. Secretary of State for Health] (2012) Plano Estadual de Saúde do Pará-PES-PA 2012-2015 [State Health Plan 2012-2015] [Online] Available at: http://bit.ly/1bZtkAL [Accessed: 27 April 2014].

Fábrega R (2007) El Camino de la Reforma: Construyendo Redes Asistenciales Basadas en la Atención Primaria [The Path of Reform: Building networks based on primary care.] Santiago: Organización Panamericana da la Salud.

FC (1988) Constituição da República Federativa do Brasil de 1988 [Constitution of the Federative Republic of Brazil 1988] [Online] Available at: http://bit.ly/1bJYlGL [Accessed: 04 February 2014].

Franco TB, Magalhães Jr HM (2004) Integralidade na Assistência À Saúde: A Organização Das Linhas do Cuidado [Comprehensive Health Care: The Organization of Care Lines] ( $2^{\text {nd }}$ ed.). São Paulo: HUCITEC.

Gama FN (2009) A Saúde da Mulher Trabalhadora no Sistema Público de Saúde: um Estudo de Caso. [The Health of Working Women in the Public Health System: A Case Study] [Online] Available at: http://bit.ly/1QhnFoX [Accessed: 23 April 2014].

Garson S (2007) Regiões Metropolitanas: Obstáculos Institucionais À Cooperação Em Políticas Urbanas [Metropolitan Regions: Institutional Obstacles on Cooperation in Urban Policies] PhD UFRJ. Available at: http://bit.ly/1E3kQjy [Accessed: 22 March 2014].

Governo do Estado de Pernambuco. Secretaria Estadual de Saúde [State of Pernambuco, Secretary of State for Health] (2014) Gerências Regionais de Saúde [Regional Health Management Offices] [Online] Available at: http://bit.ly/1zJBVTi [Accessed: 29 April 2014].

Governo do Estado de São Paulo. Subsecretaria de Desenvolvimento Metropolitano [State of São Paulo, Metropolitan Development Secretary] (2014) Região Metropolitana de São Paulo [São Paulo Metropolitan Region] [Online] Available at: http://bit.ly/1EMQPHd [Accessed: 30 April 2014].

Governo do Estado do Amazonas. Secretaria de Estado de saúde [State of Amazonas, Secretary of State for Health] (2011) Plano Estadual de Saúde-PES 2012-2015 [State Health Plan 2012-2015] [Online] Available at: http://bit.ly/1KIIruk [Accessed: 27 April 2014].

Governo do Estado do Rio Grande do Sul. Secretaria Estadual da SAúde [State of Rio Grande do Sul, Secretary of State for Health] (2011) Plano de Ação Regional Inicial-Região de Saúde Macrometropolitana de Porto Alegre [Regional Action Health Plan for the Macrometropolitana of Porto Alegre] [Online] Available at: http://bit.ly/1zvsxm0 [Accessed: 30 April 2014].

Governo do Estado do Rio Grande do Sul. Secretaria Estadual da Saúde [State of Rio Grande do Sul, Secretary of State for Health] (2014a) Politicas de Saúde do Rio Grande do Sul [Health Policies in Rio Grande do Sul] [Online] Available at: http://bit.ly/1cghEdE [Accessed: 30 April 2014].

Governo do Estado do Rio Grande do Sul. Secretaria Estadual da Saúde [State of Rio Grande do Sul, Secretary of State for Health] (2014b) Linhas de Cuidado [Lines of care] [Online] Available at: http://bit.ly/1 KbNCly [Accessed: 30 April 2014]. 
Governo do Rio de Janeiro. Portal da Saude do RJ [State of Rio de Janeiro, Secretary of State for Health] (2014) Redes de Atenção à Saúde [Healthcare Networks] [Online] Available at: http://bit.ly/1GXhrc3 [Accessed: 30 April 2014].

Grenier C (2011) Structuring an integrated care system: interpreted through the enacted diversity of the actors involved: the case of a French healthcare network. International Journal of Integrated Care 11(16): 1-15.

Griffith JR (1997) Managing the transition to integrated health care organizations. In: Conrad DA Integrated Delivery Systems: Creation, Management and Governance. Chicago: Health Administration Press.

Ham C (2006) Developing Integrated Care in the NHS: Adapting Lessons from Kaiser. Birmingham: Health Services Management Centre.

Hildebrandt H, Ripmann K (2001) Managerial Problems in Setting up an Integrated Health System: Reflections and Experiences from a German Perspective. Barcelona: WHO Integrated Care Meeting.

Holden CA, Lin V (2012) Network structures and their relevance to the policy cycle: A case study of the national male health policy of Australia. Social Science and Medicine 74(2): 228-235.

IBGE (2010) Censo 2010 [2010's Census] [Online] Available at: http://bit.ly/1Kxx7Bq [Accessed: 22 March 2014].

IBGE (2009) Indicadores Sociodemográficos e de Saúde no Brasil 2009 [SocioDemographic and Health Indicators in Brazil 2009]. Rio de Janeiro: IBGE.

Lavadenz F, Schwa N, Straatman H (2001) Redes públicas, descentralizadas y comunitarias de salud en Bolivia [Public, decentralized and community health networks in Bolivia]. Revista Pan-American Salud Pública 9(3): 182-189. Available at: http://bit.ly/1Ib8CdF [Accessed: 22 March 2014].

Leat P, Pink GH, Naylor CD (1996) Integrated delivery systems: has their time come in Canada?. Canadian Medical Association Journal 154(6): 803-809.

Martínez DMH (2004) Un Estudio de Caso de Dos Organizaciones Sanitarias Integradas in Cataluña [A Case Study of Two Integrated Health Care Organizations in Catalonia] DEd Universidad Pompeo Fabra. Available at: http://bit.ly/1GLNh6f [Accessed: 30 January 2015].

Micallef J (2000) Apports des réseaux en santé publique: conditions de mise en place et de fonctionnement en clinique et en recherche [Contributions of public health networks: conditions for setting up and running in clinical research] Thérapie 55: 541-545.

Ministerio de la Salud de Chile [Chile's Ministry of Health] (2005) Redes asistenciales. [Healthcare networks] Santiago.

Ministerio de la Salud de Peru [Peru's Ministry of Health] (1999) Redes de Servicios de Salud [Healthcare Services Networks]. Lima: Ministerio de la Salud.

Organización Panamericana de la Salud [Health Pan-American Organization] (2010) Redes integradas de servicios de salud: conceptos, opciones de politica y hoja de ruta para suimplementacion em las Americas [Pan American Health Organization (2010) integrated health care networks: concepts, policy options and roadmap for its implementation in America]. Washington.

Pointer DD, Alexander JA, Zuckerman HA (1997) Loosening the gordian knot of governance in integrated health care delivery systems. In: Conrad DA Integrated Delivery Systems: Creation, Management and Governance. Chicago: Health Administration Press. Available at: http://bit.ly/1R8It3g [Accessed: 22 March 2014]. 
Portal Brasil (2014) Saúde implanta S.O.S Emergências no Espírito Santo [Website Brazil. Health Emergencies in the Espirito Santo State] [Online] Available at: http://bit.ly/1Jn6MFc [Accessed: 23 April 2014].

Prefeitura da Cidade do Rio de Janeiro (2014) Sistema Municipal de Informações Urbanas [City Hall of Rio de Janeiro. Municipal Urban Information System] [Online] Available at: http://bit.ly/1JNop4h [Accessed: 30 April 2014].

Prefeitura de Belém (2012) Anexo I Contextualização das Dimensões Estratégicas [City Hall of Belém. Health Strategies] [Online] Available at: http://bit.ly/1Ecfi5o [Accessed: 27 April 2014].

Prefeitura de Belo Horizonte. Secretaria de Gestão Compartilhada (2014) Áreas de abrangência [City Hall of belo Horizonte. Health districts] [Online] Available at: http://bit.ly/1EMVngX [Accessed: 28 April 2014].

Prefeitura de Belo Horizonte. Secretaria Municipal de Saúde (2009) SUS-BH: Cidade Saudável - Plano Macro-estratégico Belo Horizonte 2009-2012: Documento inicial para discussão com as Gerências e Equipes do SUS-BH [City Hall of Belo Horizonte. Healthy City Strategic Plan] [Online] Available at: http://bit.ly/1IcPai8 [Accessed: 28 April 2014].

Prefeitura de Curitiba. Secretaria Municipal de Saúde (2013)] Programa Mãe Curitibana [City Hall of Curitiba. Mom's health program] [Online] Available at: http://bit.ly/1cgpdRu [Accessed: 30 April 2014].

Prefeitura de Goiânia. Secretaria Municipal de Saúde (2012) Consultas SUS [City Hall of Goiânia. Health consults] [Online] Available at: http://bit.ly/1Pks5sy [Accessed: 30 April 2014].

Prefeitura de Londrina. Secretaria Municipal de Saúde. Conselho Municipal de Saúde (2013) Relatório Anual de Gestão da Saúde 2013. [City Hall of Londrina. Annual Health Report, 2013] [Online] Available at: http://bit.ly/1QhsYEJ [Accessed: 30 April 2014].

Prefeitura do Recife (2009) Plano Municipal de Saúde 2010/2013 [City Hall of Recife. Municipal Health Plan] [Online] Available at: http://bit.ly/1zJG21O [Accessed: 29 April 2014].

Saltman RB, Figueras J (1997) European Health Care Reforms: Analysis of Current Strategies. Copenhagen: WHO, Regional Office for Europe.

Secretaria da Saúde do Estado de Goiás (2013) Redes de Saúde em Goiás são apresenta-das para técnicos e gestores [State of Goiás Health Department. Heathcare networks are introduced into management routines] [Online] Available at: http://bit.ly/1ETEHWb [Accessed: 30 April 2014].

Secretaria da Saúde do Estado do Ceará (2012) Plano Estadual de Saúde 2012-2015 [State of Ceará Health Department. State's Health Plan 2012-2015] [Online] Available at: http://bit.ly/1GXlfKl [Accessed: 27 April 2014].

Secretaria da Saúde do Estado do Ceará (2014) Curso Reforça Qualidade da Atenção nas Urgências em Hospitais [State of Ceará Health Department. Course Strengthens Quality of Care in Emergencies in Hospitals] [Online] Available at: http://bit.ly/1GLORoC [Accessed: 27 April 2014].

Secretaria de Estado de Desenvolvimento da Região Metropolitana do Distrito Federal (2014) [Federal District Health Department] [Online] Available at: http://bit.ly/1cgpJ1O [Accessed: 30 April 2014].

Secretaria de Estado de Saúde do Distrito Federal (2014) Programas [Federal District Health Department. Programs] [Online] Available at: http://bit.ly/1DQ0r07 [Accessed: 30 April 2014]. 
Secretaria de Saúde de São Bernardo do Campo (2012) Os Espaços Coletivos, a Territo-rialização e a Implantação das Linhas de Cuidado em São Bernardo do Campo - Curso: Redes de Urgência e Emergência no SUS [São Bernardo Health Department. The Collective Spaces, the Territorialization and Implementation of Care Lines in São Bernardo do Campo] [Online] Available at: http://bit.ly/1Jn8INT [Accessed: 30 April 2014].

Secretaria de Saúde do Estado da Bahia (2012a) Apresentação-Rede de Atenção às Urgências [State of Bahia Health Department. Care Network to ER] [Online] Available at: http://bit.ly/1IIFmLF [Accessed: 28 April 2014].

Secretaria de Saúde do Estado da Bahia. Conselho Estadual de Secretários Municipais de Saúde (2012b) Plano de Ação da Rede de Atenção às UrgênciaRegiãoMetropolitana de Salvador Ampliada Urgências [State of Bahia Health Department. Action plan for the Emergency Care Network] [Online] Available at: http://bit.ly/1OWfwZA [Accessed: 28 April 2013].

Shortell SM, Gillies RR, Anderson DA, Micthell JB, Morgan KL (1993) Creating organized delivery systems: the barriers and the facilitators. Hospital and Health Services Administration 38(4): 447-466.

Simoens S, Scott A (1999) Towards a Definition and Taxonomy of Integration in Primary Care. Aberdeen: University of Aberdeen.

Sunol R, Carbonell JM, Nualart L, Colomes L, Guix J, Baneres J, Costa J, Nofuentes S, Prat J (1999) Towards health care integraltion: the proposal of an evidence and management system-based model. Medicina Clinica 112(Suppl. 1): 97-105 [Article in Spanish].

Vázquez MLN, Vargas IL (2006) Redes integradas de servicios de salud: solución o problema? [Integrated networks of health services: solution or problem?] Ciencias de la Salud 4(1): 5-9.

Wan TTH, Lin BY, Ma A (2002) Integration mechanisms and hospital efficiency in integrated health care delivery systems. Journal of Medical Systems 26(2): 127143.

Warner MN (2001) Integrated care developments in Europe. Barcelona: WHO Integrated Care Meeting.

World Health Organization (2003) Diet, nutrition and the prevention of chronic diseases. Geneva: World Health Organization. Available at: http://bit.ly/1bu5BIk [Accessed: 02 July 2014]. 